guarians of parishes, by the working of this grant, are rendered by $n$ means averse to the removal of paupers to asylums, and re not as anxious for their return as they were when theimaintenance in an asylum cost the parishes more than in a rorkhouse. The masters of workhouses also are very resd to facilitate the removal of paupers who, from requing a little extra diet or supervision, militate against sppant economy of administration. The workhouse nurses and itendants are equally predisposed to favour the removal of pesons likely to give extra trouble, and the medical officers are prhaps not unwilling to accept testimony of nurses haviry this bias in certifying a patient who does not present any ery tangible symptoms of insanity. The most pernicios influence, however, is probably exercised on the friens of patients, who are induced by reports of the comfort of th county asylum to relieve themselves of the care of ged elatives who are in the slightest degree troublesome. Wher once feeble-minded persons have been sent to an asylun, medical superintendents do not find it an easy matter to retirn them to the workhouses, where their advent is by no means acceptable. Hence, they accumulate in the asyluns, diluting unduly the insane who absolutely require treatrent, thus costing for their maintenance much more than is necessary, and sometimes leading to a reduction of the general asylum dietary, which is inimical to the welfare of the insane. The remedies for this state of things I wonld suggest are-first, the abolition of the Government grant in its present form; secondly, the retention of harmless imbeciles in a special block of their parish workhouses; thirdly, an extension of the plan of aiding relatives who are milling to take charge of harmless aged persons; fourthly, the establishment of a reception hospital (as has been done in New South Wales), from which alleged lunatics could be distributed to appropriate institulions; and, fifthly, that the Commissioners in Lunacy should occasionally make stringent investigation in regard to the "facts communicated by others" in weak certificates relating to persons who have been workhouse paupers. With these changes little additional asylum accommodation will be required; without them, in a few years a much larger proportion of paupers will be certified lunatics. - I am, Sir, yours truly,

Hanwell, Nov. 13th, 1883

H. RAYNER.

\section{"STRUGGLES WITH LUNATICS."}

\section{To the Editor of THE LANCET.}

SIR,-My attention has been called to the annotation in your issue of November 3rd, entitled "Struggles with Lunatics," and as an eye-witness of the "curious" crowd collected at the railway station in question to enjoy the exhibition of a struggle with a madman, I agree with you in thinking that something ought certainly to be done "to put an end to the very unseemly struggles which every now and then excite indignation and create scandal." But I address you at present, not for the purpose of referring to this matter, but because I observe that in your issue of the loth instant you have opened your columns to the discussion of a subject in which I have felt deeply interested, since I first admitted so-called chronic and harmless lunatics into the warrs of Caterham Asylum, then hardly structurally completed, in the year 1870. At that time, under the provisions of Gathorne Hardy's " Metropolitan Poor Act," just coming into operation, an exodus was taking place of all chronic lunatics, idiots, and imbeciles from the workhouses of the metropolitan district to the large imbecile asylums of Leavesden and Caterham, the belief then being general that these persons were not sufficiently cared for in workhouses. As, however, Dr. Williams, of Haywards Heath, in his letter to you dated October 31st, advocates the relief of county asylums by refilling the wards of workhouses with chronic and harmless cases, I am induced to offer you the result of nearly ten years' experience in dealing with very large numbers of the class of cases referred to, with the conclasions at which $I$ arrived as to the best method of dealing with them. In each annual report of the Caterham Asylum from the year 1870 till 1880 , I stated my views fully, and finally summarised them in somewhat of the following Inanner:- "The question of the best means of dealing with persons in a state of chronic insanity, imbecility, or idiocy is one of pressing importance to the counties, and indeed to the whole country, for it is well known that in every county asylum much space is taken up by those cases from which if they were relieved so much the more accommodation would be found for the treatment of recent, acute, and curable cases, for which such institutions are generally so admirably adapted, but whose machinery is necessarily and properly somewhat costly. In like manner, in many workhouses chronic cases are either found to necessitate a large amount of expense for their proper separate care and treatment, or, failing this, they are very inadequately provided for, or it may be neglected. These cases are also sometimes regarded as being unsuitable for ordinary workhouse routine, and by their presence rendering the strict observance of the usual workhouse administration deficient. Under such circumstances inexpensively and carefully managed intermediate chronic asylums seem to supply the want felt by the county lunatic asylum on the one hand and by the workhouse for its relief and economical working on the other. It is a mere question of expediency whether accommodation for chronic cases should be provided as an offshoot from the parent county asylum, and be under the same management in the shape of wards added suitable for chronic cases, or whether it should be separately erected and conducted as a separate establishment and be under distinct management. My opinion on these points is that where large numbers are to be dealt with, as in the metropolitan counties, a separate establishment is the better arrangement (and the same might be carried out in the counties by combination), but, where smaller numbers are to be provided for, that this is to be most economically and efficiently done by the addition of blocks of buildings specially adapted for chronic cases to the parent asylum. In every case I am strongly of opinion (considering the liability there is to relapse in many forms of mental disease) that chronic accommodation should most certainly act in close association with the county asylum, every facility being given by legislation and otherwise for the county asylum easily to transfer its chronic cases, and an equal facility for the chronic asylum to return cases to the county asylum upon their showing signs of relapse or when, in the opinion of the medical superintendent, such a step is necessary. For this reason it is obvious that chronic accommodation sbould not be provided at too great a dis. tance from the parent acute asylum. Much, at all events temporary, relief to overcrowding of county asylums, as pointed out by Dr. Williams, is also to be obtained by boarding out suitable cases under suitable conditions; but I refrain from entering upon this branch of the subject at present, as I feel I have already trespassed too far on your valuable space. - I am, Sir, your obedient servant,

$$
\text { JAMES ADAM, M.D., }
$$

Late Medical Superintendent Caterham Asylum. Malling Place, Kent, Nov. 10th, 1883.

\section{To the Editor of THE LANCET.}

SIR,-In an editorial note in your last issue you mention "lunatic taming" as an art, and in this you are perfectly correct and none know better that there is such an art or give it fuller recognition than asylum medical officers. It is with them a matter of every-day experience that some of their attendants can tone down and wheedle into calm an excited and violent patient who in other hands would be a very demon of noise and destruction. That all cannot do this, try as they may, is equally well known, and that it is the gift of only a very limited number of individuals is generally admitted. It is not infrequently found that $a$ medical officer or attendant in no way overbearing or severe in manner, who has been frequently attacked and "knocked over" by the excited patients, is succeeded by another who for years treats and mixes with the same patients and is never once struck at or even threatened. This Rarey-like charm is, as I have said, not to be acquired by all, as the want of it in many honest and kind-hearted men and women who have tried hard and long to gain such an influence amply testifies. But then it must be admitted that there are cases where the most successful lunatic tamer is as ineffectual as the policeman appears to be. In these cases the mind of the patient is for a time lashed in to such a fury that all attempts at soothing pass unnoticed, and for this simple reason can have no effect. That the police have not this gift is clear, and that someone who has "should be called in by the magistrates when they have to do with the insane" is equally clear. Where then are these lunatic tamers to be found? Where but amongst that much abused 
class, our asylum attendants, where the natural gift is often found brightened and brought to perfection by constant use ?

You find fault with superintendents because not more than one-third of the attendants attached to asylums are possessed of this evidently rare power. I think your proportion rather flattering to superintendents in general-until 1 remember that mad doctors have

"To climb perfection's sacred height,"

and stay there to gain the brotherly love of some people. If these same unfortunate superintendents say, as I have, or even hint that this "taming process" will not act in all cases, such belief on their part is to be set down as "simply the outcome of ignorance how to treat the insane." May I ask if these men of equal brains and education with their professional fellows, who have spent the better part of their lives in the study of the best mode of treatment of the insane, be ignorant of this best mode, who, in the name of common sense, are to be their informants or instructors? Had someone had a revelation from heaven on the subject he might be set up as a censor, but even he in these degenerate days might be doubted.

Your remarks as to some new manner of treatment of Mnnatics brought before magistrates being urgently needed is timely and to the point. Why should we not have a receiving house under experienced medical management to send all doubtful and remanded cases, such as has been in active operation with such good results in New South Wales for some time past? Here all cases would be under observation and a careful and definite diagnosis of them could be made, which is more than can generally be done now by an inexperienced gentleman who has to examine his patien in a dark or semi-dark cell.

I am, Sir, yours faithfully,

Northampton County Asylum, S. A. K. STRAHAN, M.D. Nov. 5th, 1883 .

\section{THE NEW DRAINAGE OF MENTONE.}

\section{To the Editor of THE LANCET.}

SIR,-An article which appeared recently in your journal on "the new drainage of Mentone" has been widely circulated out of the profession, and has been much discussed at Mentone. On Nov. 1st, at the first meeting of the Society of Mentone Medical Practitioners, of which I have the honour to be president, I drew the attention of the members present, thirteen in number, to the statements of your correspondent. The medical members of the town Bureau a'Hygiène, who were present, gave detailed information as to what had been done and was doing with reference to the drainage works. The subject was subsequently discussed in all its bearings, and I was requested by the Society to communicate to you the information obtained.

Previous to the advent of strangers there was no drainage system whatever at Mentone, as is the case in all the small Italian towns at the present day, the plan adopted obviating, as the inhabitants think, all necessity thereof. Nearly all the inhabitants are landed proprietors, and depend all but entirely on human manure for fertilising their olive, lemon, and orange trees. The excreta, as also the house slops (small in quantity in a land where soap and water are but sparingly used), are collected in small barrels. When these are full they are carried on donkey-back to the mountain terraces on which the trees grow. A trench is dug around the base of each tree, and the manure, mixed with earth, therein deposited. It really is the primitive earth system. Thus, although the atmosphere inside the house is occasionally tainted, there is no collection of stagnant fermenting fæces in or near the house. The rain water and more abundant washing slops run down the street in a gutter, as your correspondent correctly states.

When hundreds, nay thousands, of visitors arrived at Mentone, this primitive earth system could no longer be applied to them, and cesspools were built to all the villas and hotels, with ventilating shafts carried from the cesspool to the roof of the house. This system still universally obtains, and it will be difficult, if not impossible, to alter it. Mentone is very peculiarly situated. The town itself is built on the shoulders and extremity (menton, chin) of a promontory that terminates a mountain 1500 feet high, itself lying as a buttress against this mountain amphitheatre, 4000 feet high, which circumscribes and forms the district
The ascent from the shore to the old castle and cemetery, which occupy the apex of the town, is very precipitous rising above 200 feet in half a mile. In the bays, east and west of the old town, there is very little level ground, the ascent beginning very near the shore line. Everywhere the rock is near the surface. The rains at Mentone are all bat tropical, especially in spring and autumn. Often three or four inches of rain fall in twelve or twenty-four hours, carrying with it soil and sand in such quantities as to render the sea turbid, quite yellow, for a mile or more from the shore. The new drains are merely constructed to carry off these floods of rain water, which inundate the lower parts of the town, as also what are called "eaux menageres," or house water, and are not permitted to receive human excreta, They are made high and wide : first, that they may be able to carry off these sudden masses of water; secondly, that they may not be choked with the soil and sand which the rain water brings with it; and, thirdly, that if they are so choked men may be able to get inside and clean them.

When I first arrived at Mentone, in 1859, the lower parts of the town were occasionally inundated as deseribed after heavy rains, and such a state of things was accepted by the population as one of the necessary conditions of life. With above two thousand winter visitors, however, and a very much higher state of civilisation, such inundation can no longer be accepted; hence the size of the drains now building. Moreover, none of the houses in the old town have been connected with the new drains, and a clause has been adopted by which, should such a connexion be made in the future, a proper syphon trap will have to be made between the drains and the houses. The inhabitants are to pour their house slops into them by trapped gullies, but not the freces, which are to be collected as of yore (in the old native town) and carried off to the country.

It is the presence of the numerous visitors inhabiting the villas, and assembling in large hotels to the number of 100 , 200 , or more (the Hotel Victoria has 200 beds), that ronders the drainage of the locality difficult. Small sewers would have burst with the heavy rains, and have overflowed whilst it is feared that the large sewers now building would allow solid matter to collect (especially during the five months' summer drought) were they used for sewage. There is a water company now in operation at Mentone, which in the season distributes daily above four hundred cubic metres of water (the metre is three feet four inches) to its clients, all of which finds its way to the sewers, but it is thought that even that amount would be insufficientito scour efficiently the main drains in the level part of the town if the latter were used as sewage drains. The old town is to be still better off, for a small stream or rivulet from the valley of Mentone, at a higher elevation, is to be daily let into the sewer in the Rue Longue described by your correspondent

It has been thought best, therefore, to continue the system of cesspools, at least for the present. The latter are, or ought to be, always emptied by the pneumatic apparatus so much used in Paris and elsewhere on the Continent. When it is used by the hotel and villa proprietors, and not shirked to avoid expense, there is no smell or inconvenience whatever. A vacuum is established in a large cask or tab drawn on wheels, like a water tub, only larger. The cesspool is con. nected with it by a gutta-percha tube, and on turning a valve the contents of the cesspool are precipitated into the tub by atmospheric pressure. The difficulty is to know what to do with the contents of the tubs. A locality was at first given to the contractor a long way up one of the vallevs, but objections have been raised to this mode of disposal of the town sewage, and it has been recently determined by the municipal authorities to throw it into the sea at a distance from the land, on the maritime side of the new jetty or pier. A ledge of rocks which advances into the sea, con. tinuing the promontory on which Mentone is built, will, itis hoped, render this feasible and safe. There is a strong sea current trending along the coast from east to west, which will, it is thought, carry off the sewage to the sea, away from the coast.

The Medical Society suggested to the town authorities to provide flat-bottomed boats and a steam launch, and to tor the sewage out to sea daily, but the heary expense this plan would have entailed has negatived it, at least for the present.

Up to the present time the system described-well-brilt well-cemented cesspools, with good and efficient ventilation at the roof of the house-has sufficed to keep Mentone exceptionally healthy. During the twenty-three years I h que 